\title{
A new Chinese Mesozoic stick insect
}

Andre Nel and Emmanuel Defosse

Acta Palaeontologica Polonica 56 (2), 2011: 429-432 doi: http://dx.doi.org/10.4202/app.2009.1108

Renphasma sinica gen. et sp. nov. is described from the Early Cretaceous Yixian Formation in Liaoning. It has the general habitus of the Mesozoic "stick-insects", with a short thorax, and broad and long tegmina, as long as the hindwings. Its pattern of tegmina venation is typical of the Mesozoic Phasmatodea, also present in the Eocene stick insect family Gallophasmatidae, viz. archaeorthopteran organisation of median and cubital veins. On the other side it has a vomer typical of modern Phasmatodea, both supporting the hypothesis that the Mesozoic, Cainozoic, and modern stick insects belong to the same clade. The pattern of dark and hyaline spots on the wings of Renphasma is probably related to mimicry with plants.

André Nel [anel@mnhn.fr] and Emmanuel Delfosse [delfosse@mnhn.fr], CNRS UMR 7205, Entomologie, Muséum national d'histoire naturelle, CP 50, 45, rue Buffon, 75005 Paris, France.

This is an open-access article distributed under the terms of the Creative Commons Attribution License (for details please see creativecommons.org), which permits unrestricted use, distribution, and reproduction in any medium, provided the original author and source are credited.

FoF Full text $(314.0 \mathrm{kB})$ 